ISSN : 2354 - 6034 (Print)

ISSN : 2599 - 0187 (Online)

\title{
PENANGANAN SENGKETA EKONOMI SYARIAH PERSPEKTIF CITA HUKUM DI PENGADILAN TINGGI AGAMA SEMARANG
}

\author{
Mohammad Jamaludin \\ Fakultas Ekonomi dan Bisnis Islam IAIN Palangka Raya \\ Email: mjamaluddin13@yahoo.com
}

\begin{abstract}
This article examines the handling of sharia economic disputes from the perspective of the ideals of law in the Religion High Court of Semarang, considering that up to now many decisions of the Religious High Court have been pursued at the cassation level (Supreme Court). The focus of this research study is to answer a number of issues, namely: how is the mechanism for handling sharia economic disputes in the Religion High Court of Semarang, what is the legal basis used by judges in the process of examining sharia economic disputes, and how the review of legal ideals towards handling sharia economic disputes in the Religion High Court of Semarang.

Judging from the type, this article was categorized as field research with an empirical juridical approach. In analyzed the data, the writer used descriptive-analytical methods, by described primary data that the author has obtained in the Religion High Court of Semarang, supplemented with secondary data related to handling sharia economic disputes in the Religion High Court, then analyzed using the legal ideal theory which includes justice, legal certainty, and expediency.

Based on the results of the research conducted by the writer in the Religion High Court of Semarang, the writer can conclude that, the handling of sharia economic disputes in the Religion High Court of Semarang has not been fully implemented as it should. The handling of sharia economic disputes in the Religion High Court of Semarang is carried out by examining and adjudicate cases based on facts / sitting cases contained in the appeal case file sent by the religious court that has examined and decided the case at the first level, plus an additional examination if the judge consider there are things that require clarity or to add to the completeness of evidence. A review of the legal ideals for handling sharia economic disputes in the Religion High Court of Semarang include: in terms of the ideals of the law of justice, judges in realizing the ideals of the law of justice are still constrained by vague provisions in the laws and regulations in which regulate about the procedures for examining sharia economic disputes in the level of appeal, which makes the judge unable to realize the desired justice. Judging from the ideals of legal certainty, the obstacle in realizing this legal ideal is the absence of special provisions regulate about civil procedural law (procedures for
\end{abstract}




\title{
Mohammad Jamaludin
}

examining cases), especially sharia economic disputes at the appellate court, additionally there are several Supreme Court jurisprudences that are conflicting/contradicting. While in terms of the legal ideal of expediency, some have fulfilled this legal ideal because it is in accordance with the provisions that regulate the costs of handling cases and the duration of handling cases.

Keywords: Economic Dispute, Legal Ideals, Sharia Economic.

\begin{abstract}
ABSTRAK
Artikel ini mengkaji tentang penanganan sengketa ekonomi syariah perspektif cita hukum di Pengadilan Tinggi Agama Semarang, mengingat hingga saat ini banyak putusan Pengadilan Tinggi Agama diupayakan hukum di tingkat kasasi. Fokus kajian penelitian ini adalah untuk menjawab beberapa persoalan, yaitu: bagaimana mekanisme penanganan sengketa ekonomi syariah di Pengadilan Tinggi Agama Semarang, apa dasar hukum yang digunakan hakim dalam proses pemeriksaan sengketa ekonomi syariah, dan bagaimana tinjauan cita hukum terhadap penanganan sengketa ekonomi syariah di Pengadilan Tinggi Agama Semarang..

Dilihat dari jenisnya, artikel ini dikategorikan sebagai penelitian lapangan (field research) dengan pendekatan yuridis empiris. Dalam menganalisis data, penulis menggunakan metode deskriptif-analitis, yaitu dengan menggambarkan data primer yang telah penulis dapatkan di Pengadilan Tinggi Agama Semarang, dilengkapi dengan data sekunder terkait penanganan sengketa ekonomi syariah di Pengadilann Tinggi Agama, selanjutnya dianalisis menggunakan teori cita hukum yang meliputi keadilan, kepastian hukum, dan kemanfaatan.

Berdasarkan hasil penelitian yang penulis lakukan di Pengadilan Tinggi Agama Semarang, penulis dapat menyimpulkan bahwa, penanganan sengketa ekonomi syariah di Pengadilan Tinggi Agama Semarang belum sepenuhnya berjalan sebagaimana mestinya. Penganganan sengketa ekonomi syariah di Pengadilan Tinggi Agama Semarang dilaksanakan dengan cara memeriksa dan mengadili perkara secara ulang berdasarkan fakta/duduk perkara yang terdapat dalam berkas perkara banding yang dikirimkan oleh pengadilan agama yang telah memeriksa dan memutus perkara pada tingkat pertama, ditambah dengan pemeriksaan tambahan apabila hakim berpendapat ada hal-hal yang memerlukan kejelasan atau untuk menambah kesempurnaan pembuktian. Tinjauan cita hukum terhadap penanganan sengketa ekonomi syariah di Pengadilan Tinggi Agama Semarang di antaranya: ditinjau dari cita hukum keadilan, hakim dalam mewujudkan cita hukum keadilan masih terkendala dengan ketentuan yang samar dalam peraturan perundang-undangan yang mengatur tentang bagaimana tata cara pemeriksaan sengketa ekonomi syariah di tingkat banding, yang mana hal ini menjadikan hakim tidak dapat mewujudkan keadilan yang diinginkan. Ditinjau dari cita kepastian hukum, kendala dalam mewujudkan cita hukum ini adalah tidak adanya ketentuan khusus yang mengatur tentang hukum acara perdata (tata cara pemeriksaan perkara) khususnya sengketa ekonomi syariah pada peradilan tingkat banding, ditambah lagi terdapat beberapa yurisprudensi Mahkamah Agung yang saling bertolak belakang/bertentangan. Sedangkan ditinjau dari cita hukum kemanfaatan, sebagian telah memenuhi cita hukum ini karena telah sesuai dengan ketentuan yang mengatur tentang biaya penanganan perkara dan jangka waktu penanganan perkara.

Kata kunci: Sengketa Ekonomi, Cita Hukum, Ekonomi Syariah
\end{abstract}

\section{PENDAHULUAN}

Penyelenggaraan lembaga kekuasaan kehakiman diatur dalam pasal 18 UndangUndang Nomor 48 Tahun 2009 tentang Kekuasaan Kehakiman yang menyatakan bahwa:

"Kekuasaan kehakiman dilakukan oleh sebuah Mahkamah Agung dan badan peradilan yang berada di bawahnya dalam lingkungan peradilan umum, lingkungan peradilan agama, lingkungan peradilan militer, lingkungan peradilan tata usaha negara, dan oleh sebuah Mahkamah Konstitusi”.

$\overline{15}$ Jurnal Al Qardh, 5(1), 14-37

Copyright (C) 2020 by Al-Qardh, p-ISSN 2354-6034; e-ISSN 2599-0187 


\section{Mohammad Jamaludin}

Ketentuan ini menggambarkan susunan dan badan peradilan mengikuti model piramida yang berpuncak di Mahkamah Agung dan Mahkamah Konstitusi sebagai badan peradilan tertinggi, sehingga masing-masing lembaga peradilan memiliki kewenangan masing-masing. ${ }^{1}$

Wewenang badan peradilan dalam lingkungan peradilan agama diatur dalam pasal 49 Undang-Undang Nomor 3 Tahun 2006 tentang Peradilan Agama yang menyatakan bahwa:

"Pengadilan agama bertugas dan berwenang memeriksa, memutus, dan menyelesaikan perkara di tingkat pertama antara orang-orang yang beragama Islam di bidang: perkawinan, waris, wasiat, hibah, wakaf, zakat, infaq, shadaqah dan ekonomi syari'ah."

Dalam lingkungan peradilan agama, peradilan disusun dalam dua tingkatan, yaitu peradilan tingkat pertama, yakni Pengadilan Agama dan peradilan tingkat banding, yakni Pengadilan Tinggi Agama. Dua peradilan ini disebut sebagai judex facti ${ }^{2}$, sedangkan Mahkamah Agung mempunyai fungsi sebagai judex juris ${ }^{3}$.

Hakim pada peradilan tingkat pertama dan peradilan banding memeriksa fakta hukum sebagai alas perkara yang kemudian mencocokan fakta hukum tersebut terhadap hukum yang menjadi landasan yuridis berperkara. Fakta hukum adalah fakta yang bersentuhan dengan hukum, yakni fakta yang diatur oleh hukum, baik mengenai pembuktiannya, substansinya, maupun akibat hukumnya. Fakta hukum dapat diklasifikasikan menjadi dua jenis, yaitu peristiwa hukum dan perbuatan hukum. ${ }^{4}$ Berbeda dengan peradilan tingkat pertama dan peradilan banding, peradilan tingkat kasasi bukan peradilan tingkat tiga, karena pengadilan tingkat kasasi tidak melakukan pemeriksaan terhadap peristiwa atau fakta hukum. Akan tetapi, peradilan pada tingkat ini (kasasi) menilai benar atau tidaknya penerapan hukum dalam putusan.

Penanganan sengketa ekonomi syariah pada Pengadilan Tinggi Agama (judex facti Pengadilan Tingkat banding) dilakukan melalui beberapa tahapan, yaitu; merumuskan fakta, mencari hubungan sebab akibat dan mereka-reka probabilitas. Langkah-langkah pemeriksaan perkara seperti ini merupakan mekanisme pemeriksaan perkara dalam lingkup judex facti..$^{5}$

Peradilan tingkat banding merupakan peradilan judex facti tingkat kedua. Fungsi ini melekat, karena badan peradilan tingkat banding mempunyai wewenang melakukan koreksi terhadap putusan pengadilan agama, bertindak melakukan pemeriksaan ulang terhadap perkara secara keseluruhan, sebagaimana diatur dalam Pasal 6 Undang-Undang Nomor 20 Tahun 1947 tentang Pengadilan Peradilan Ulangan, yang menyatakan bahwa:

"Dari putusan-putusan Pengadilan Negeri di Jawa dan Madura tentang perkara perdata, yang

${ }^{1}$ Moh. Amir Hamzah, Hukum Acara Perdata Peradilan Tingkat Banding, (Malang: Setara Press, 2013), hlm. 3.

${ }^{2}$ Judex facti merupakan kewenangan hakim dalam memeriksa dan memutus perkara berdasarkan fakta.

${ }^{3}$ Frase judex juris, artinya Mahkamah Agung hanya mempertimbangkan masalah hukum. Dalam tingkat kasasi, hakim hanya memeriksa apakah putusan tersebut sesuai dengan hukum atau masalah penerapan hukum, dan tidak memeriksa fakta perkara yang itu menjadi fungsi judex facti (yaitu pengadilan tingkat pertama dan pengadilan banding).

${ }^{4}$ A. Mukti Arto, Pembaruan Hukum Islam melalui Putusan Hakim, (Yogyakarta: Pustaka Pelajar, 2015), hlm. 43.

${ }^{5}$ Moh. Amir Hamzah, Hukum Acara Perdata ..., hlm. 5. 


\section{Mohammad Jamaludin}

tidak ternyata, bahwa besarnya harga gugat ialah seratus rupiah atau kurang, oleh salah satu dari pihak-pihak (partijen) yang berkepentingan dapat diminta, supaya pemeriksaan perkara diulangi oleh Pengadilan Tinggi yang berkuasa dalam daerah masing-masing”.

Fungsi judex facti pengadilan banding juga diatur pada Pasal 15 ayat (1) UndangUndang Nomor 20 Tahun 1947 tentang Pengadilan Peradilan Ulangan yang menyatakan:

"Pengadilan Tinggi dalam pemeriksaan ulangan memeriksa dan memutuskan dengan tiga Hakim, jika dipandang perlu, dengan mendengar sendiri kedua belah pihak atau saksi”.

Wewenang ini dipertegas oleh Mahkamah Agung melalui putusannya Nomor 951 K/Sip/1973, tanggal 9 Oktober 1975 yang menyatakan:

"Cara pemeriksaan perkara perdata di tingkat banding-pengadilan tinggi yang hanya memeriksa keberatan-keberatan yang diajukan oleh pembanding saja, adalah salah. Seharusnya Majelis Hakim Banding juga melakukan pemeriksaan ulang atas seluruh perkara tersebut, baik faktanya, maupun penerapan hukumnya yang telah diputuskan oleh hakim pertama". 6

Demikian juga dalam putusan Mahkamah Agung Nomor 194 K/Sip/1973, tanggal 30 November 1976 dinyatakan bahwa:

"Pengadilan Tinggi sebagai Peradilan tingkat banding, dalam memeriksa perkara perdata yang dimohon banding, harus memeriksa dan memberikan putusan perkara tersebut secara keseluruhannya, baik yang konvensi ${ }^{7}$ maupun yang rekonvensi ${ }^{8}$ yang telah diputus oleh peradilan tingkat pertama". 9

Dan dalam putusan Mahkamah Agung Nomor 3136 K/Sip/1983 juga dinyatakan bahwa:

“... sesuai ketentuan pasal 15 ayat (1) UU No. 20 Tahun 1947, pengadilan tinggi berwenang melakukan sendiri pemeriksaan tambahan, bahkan cara yang demikian lebih efektif karena pengadilan tinggi lebih tau hal-hal apa saja yang hendak diperiksa, namun jika pengadilan hendak melakukan sendiri pemeriksaan tambahan langsung kepada para pihak harus benarbenar dipertimbangkan faktor biaya yang harus dipikul para pihak. Sehubungan dengan itu, tidak mutlak pelaksanaan pemeriksaan tambahan mesti didelegasikan pengadilan tinggi kepada pengadilan negeri".

Walaupun peradilan banding merupakan peradilan judex facti tingkat kedua, akan tetapi dalam praktik beracara (yaitu dalam proses pemeriksaan perkara) yang telah berjalan selama ini berpedoman pada Pasal 357 Reglement op de Burgerlijke Rechtsvordering (Rv)

\footnotetext{
${ }^{6}$ Hulman Panjaitan, Kumpulan Kaidah Hukum Putusan Mahkamah Agung Republik Indoneisa Tahun 1953 s/d 2008 Berdasarkan Penggolongannya, (Jakarta: Prenadamedia Group, 2016), hlm. 160.

${ }^{7}$ Istilah konvensi sebenarnya merupakan istilah untuk menyebut gugatan awal atau asli. Istilah ini memang jarang digunakan dibanding istilah gugatan karena istilah konvensi baru akan dipakai apabila ada rekovensi (gugatan balik tergugat kepada penggugat).

8 Rekovensi adalah gugatan balik yang disampaikan oleh tergugat sehubungan dengan gugatan penggugat.

${ }^{9}$ Hulman Panjaitan, Kumpulan Kaidah Hukum ..., hlm. 160.
} 


\section{Mohammad Jamaludin}

10.

Di dalam Pasal $357 \mathrm{Rv}$ dinyatakan bahwa:

"Perkara kemudian oleh Hakim Banding yang bersangkutan tanpa banyak proses diputus berdasarkan surat-surat saja, tetapi ia berwenang sebelum menjatuhkan putusan akhir untuk memberikan putusan persiapan atau putusan sela".

Menurut M. Yahya Harahap, alasan pengadilan tingkat banding menjadikan Pasal 357 Rv sebagai pedoman berdasarkan kebutuhan beracara, karena penerapannya dianggap sangat bermanfaat menjadi landasan beracara (process doelmatigheid). ${ }^{11}$

Ketentuan lain yang digunakan pengadilan tingkat banding sebagai dasar hukum dalam proses tata cara pemeriksaan berdasarkan surat-surat atau berkas perkara adalah putusan Mahkamah Agung Nomor 879 K/Sip/1974. Dalam putusan ini dinyatakan bahwa: "...Pengadilan tinggi memeriksa dan memutus perkara pada tingkat banding berdasarkan berkas perkara yang dikirimkan pengadilan negeri kepada pengadilan tinggi; hal itu tidak berarti putusan yang dijatuhkan tanpa dihadiri pihak-pihak yang berperkara tidak sah, karena sistem yang demikian merupakan prosedur biasa dalam tingkat banding...". ${ }^{2}$

Bertitik tolak dari kedua ketentuan di atas dikaitkan dengan praktik peradilan yang telah berjalan selama ini, proses tata cara pemeriksaan perkara dalam tingkat banding cukup singkat, yaitu terdiri dari tiga tahap, yaitu: Pertama, proses administrasi yustisial (memeriksa pembayaran biaya banding dan kelengkapan berkas perkara, pendaftaran perkara dalam register banding, panitera menyampaikan berkas perkara kepada ketua pengadilan tinggi, menyerahkan berkas perkara kepada majelis yang ditunjuk). Kedua, proses pemeriksaan dan penyelesaian perkara (memberikan kesempatan masing-masing anggota mempelajari berkas perkara, mengadakan musyawarah untuk mengambil putusan). Ketiga, pengucapan putusan. Jadi, dalam proses pemeriksaan perkara dalam tingkat banding tidak ada pemanggilan para pihak, proses jawaban, replik dan duplik, penyampaian alat bukti maupun pemeriksaan, ahli ataupun pemeriksaan setempat, dan tidak ada proses penyampaian konklusi. ${ }^{13}$

Jika dicermati lebih mendalam, tidak berjalannya fungsi judex facti peradilan tingkat banding yang diatur dalam Pasal 6 dan Pasal 15 ayat (1) Undang-Undang Nomor 20 Tahun 1947 tentang Pengadilan Peradilan Ulangan, dan yurisprudensi Mahkamah Agung Nomor 951 K/Sip/1973, Nomor 194 K/Sip/1973, dan Nomor 3136 K/Sip/1983 karena dalam ketentuan-ketentuan tersebut tidak terdapat ketentuan khusus yang mengatur perihal bagaimana tata cara pemeriksaan perkara di pengadilan tingkat banding, yang pada akhirnya pengadilan tingkat banding menggunakan pasal $357 \mathrm{Rv}$ sebagai dasar pelaksanaan praktik

${ }^{10}$ Reglement op de Burgerlijke Rechtsvordering (Rv) atau Reglemen Hukum Acara Perdata untuk Golongan Eropa, Stb.1847 No. 52, jo Stb. 1849, merupakan hukum acara yang berlaku khusus bagi golongan Eropa dan bagi mereka yang dipersamakan untuk berperkara di Raad van Justitie dan Hooggerechtshof. Dengan dihapusnya Raad van Justitie dan Hooggerechtshof maka dipergunakan dan dipertahankan sebagaimana tertuang dalam Pedoman Pelaksanaan Tugas dan Administrasi Pengadilan Buku I dan II, Mahkamah Agung Republik Indonesia, Tahun 2003/2004, hlm. 60 dan hlm. 126. (Selanjutnya disebut Rv)

${ }^{11}$ M. Yahya Harahap, Kekuasaan Pengadilan Tinggi dan Proses Pemeriksaan Perkara Perdata dalam Tingkat Banding, (Jakarta: Sinar Grafika, 2006), hlm. 112.

${ }^{12}$ Moh. Amir Hamzah, Hukum Acara Perdata ..., hlm. 7.

${ }^{13}$ M. Yahya Harahap, Kekuasaan Pengadilan ..., hlm. 112-114. 


\section{Mohammad Jamaludin}

beracara di pengadilan tingkat banding karena dinilai lebih bermanfaat.

Tidak berjalannya fungsi judex facti dengan baik dan konsisten di pengadilan tingkat banding mengakibatkan para pencari keadilan dan para pihak yang merasa dirugikan dengan putusan pengadilan tingkat pertama melakukan upaya hukum permohonan kasasi ke Mahkamah Agung.

Dari data yang penulis dapatkan dari Direktorat Putusan Mahkamah Agung, setidaknya terdapat 11 putusan kasasi sengketa ekonomi syariah yang telah diputus oleh Mahkamah Agung dari tahun 2009 sampai saat ini, dan 4 di antaranya dikabulkan dengan amar putusan membatalkan putusan pengadilan tinggi agama dan mengadili sendiri sengketa ekonomi syariah tersebut.

Berikut ini penulis sajikan dalam bentuk tabel, putusan pengadilan di tingkat kasasi yang membatalkan putusan pengadilan tinggi agama dan mengadili sendiri:

\begin{tabular}{|c|c|c|c|}
\hline No. & No. Perkara & Sengketa & Amar Putusan \\
\hline 1 & $\begin{array}{l}362 \\
\mathrm{~K} / \mathrm{Ag} / 2013\end{array}$ & $\begin{array}{l}\text { Take Over } \\
\text { Pembiayaan } \\
\text { Murabahah }\end{array}$ & $\begin{array}{lrrr}\text { Membatalkan putusan Pengadilan } & \text { Tinggi } \\
\text { Agama } & \text { Padang } & \text { Nomor } \\
\text { 46/Pdt.G/2012/PTA.Pdg., yang membatalkan } \\
\text { putusan Agama } & \text { Padang } & \text { Nomor } \\
\text { 907/Pdt.G/2011/PA.Pdt. } & & \end{array}$ \\
\hline 2 & $\begin{array}{l}528 \\
\mathrm{~K} / \mathrm{Ag} / 2015\end{array}$ & $\begin{array}{l}\text { Pembiayaan } \\
\text { Murabahah bil } \\
\text { Wakalah }\end{array}$ & $\begin{array}{l}\text { Membatalkan putusan Pengadilan } \\
\text { Agama Tinggi } \\
\text { 137/Pdt.G/2014/PTA.JK., yang memperbaiki } \\
\text { putusan Pengadilan Agama Jakarta Selatan } \\
\text { Nomor 2400/Pdt.G/2013/PA.JS. }\end{array}$ \\
\hline 3 & $\begin{array}{l}569 \\
\mathrm{~K} / \mathrm{Ag} / 2015\end{array}$ & $\begin{array}{l}\text { Pembiayaan } \\
\text { Ijarah Multijasa }\end{array}$ & $\begin{array}{lcc}\text { Membatalkan putusan Pengadilan } & \text { Tinggi } \\
\text { Agama } & \text { Semarang } & \text { Nomor } \\
\text { 160/Pdt.G/2014/PTA.Smg., yang memperbaiki } \\
\text { putusan Pengadilan Purbalingga } & \text { Nomor } \\
\text { 1721/Pdt.G/2013/PA.Pbg. }{ }^{14} & \end{array}$ \\
\hline 4 & $\begin{array}{l}272 \\
\mathrm{~K} / \mathrm{Ag} / 2015\end{array}$ & $\begin{array}{l}\text { Pembiayaan } \\
\text { Mudharabah } \\
\text { Muqayyadah }\end{array}$ & $\begin{array}{lcc}\text { Membatalkan putusan Pengadilan } & \text { Tinggi } \\
\text { Agama Jakarta } & \text { Nomor } & 5 / \text { Pdt.G/2014/PTA.JK } \\
\text { yang membatalkan putusan Pengadilan } & \text { Agama } \\
\text { Jakarta } & \text { Selatan } & \text { Nomor } \\
\text { 1695/Pdt.G/2012/PA.JS. } & & \end{array}$ \\
\hline
\end{tabular}

Jika diperhatikan secara seksama, semua putusan di tingkat kasasi membatalkan putusan pengadilan tinggi agama dan mengadili sendiri perkara tersebut. Hal ini mengindikasikan ada inkonsistensi fungsi peradilan judex pacti dengan fungsi judex juris

14 http://putusan.mahkamah.go.id/pengadilan/mahkamah-agung/direktori/perdata-agama/ekonomisyariah, diakses tanggal 13 Desember 2016.

15 Pokja Laporan Tahunan MARI, Laporan Tahunan 2015 Mahkamah Agung Republik Indonesia, (Jakarta: Mahkamah Agung RI, 2016), hlm. 327. Bisa diakses di http://www.pembaruanperadilan.net/v2/unduh-dokumen/laptah-ma/ 


\section{Mohammad Jamaludin}

yang ditunjukkan dengan upaya Mahkamah Agung mengadili sendiri perkara sengketa ekonomi syariah tersebut, yang mana hal ini menjadikan Mahkamah Agung mempunyai dua fungsi, yaitu sebagai judex facti dan judex juris sekaligus. Pertimbangan hakim Mahkamah Agung dalam membatalkan putusan pengadilan tinggi agama-pun beragam, bisa karena hakim salah dalam memahami fakta hukum atau hakim salah dalam pertimbangan hukum yang pada akhirnya hakim salah membuat putusan.

Secara konseptual, apabila mekanisme terkait tata cara pemeriksaan ulangan diterapkan pada peradilan tingkat banding, akan dapat mengatasi upaya hukum kasasi atas putusan pengadilan banding yang mana hal ini menjadikan pengadilan banding sebagai penyaring perkara perdata yang diupaya-kan hukum di tingkat kasasi, dan pengadilan banding bisa menjadi peradilan judex facti tingkat akhir, sehingga putusannya mempunyai kekuatan hukum tetap (in kract van gewijsde).

Pemahaman pemeriksaan ulangan yang penulis maksud di sini adalah bahwa hakim pengadilan tinggi melakukan pemeriksaan perkara dari mulai diajukan hingga dibuat putusan. ${ }^{16}$ Hakim pengadilan tinggi memeriksa duduk perkara atau fakta maupun penerapan hukumnya. ${ }^{17}$ Hal ini berbeda dengan pemeriksaan di tingkat kasasi, pada tingkat kasasi, hakim hanya memeriksa substansi masalah penerapan hukumnya, tidak pada memeriksa duduk perkara atau fakta hukumnya. Sedangkan dalam pemeriksaan di tingkat banding akan diperiksa fakta hukumnya, karena itu hakim banding akan melakukan penilaian terhadap bukti-bukti yang diajukan dalam perkara. ${ }^{18}$

Berangkat dari permasalahan yang penulis paparkan di atas, penulis berkeinginan untuk melakukan penelitian yang lebih mendalam dan mencoba untuk menganalisis permasalahan terkait penanganan sengketa ekonomi syariah di tingkat banding atau di Pengadilan Tinggi Agama. Penulis akan melakukan studi di Pengadilan Tinggi Agama Semarang, penulis memilih Pengadilan Tinggi Agama Semarang karena: Pertama, pengadilan ini telah memutuskan 15 sengketa ekonomi syariah (terbanyak di antara Pengadilan Tinggi Agama se-Indonesia. ${ }^{19}$ Kedua; dari 15 sengketa ekonomi syariah yang telah diputus, salah satunya telah dibatalkan oleh Mahkamah Agung di tingkat kasasi. Oleh karena itu, judul penelitian yang penulis angkat pada saat ini adalah "Penanganan Sengketa Ekonomi Syariah Perspektif Cita Hukum di Pengadilan Tinggi Agama Semarang”.

Disinilah peneliti akan membahas mengenai bagaimana mekanisme penanganan penyelesaian sengketa ekonomi syariah di Pengadilan Tinggi Agama Semarang, dasar hukum yang digunakan Hakim Pengadilan Tinggi Agama Semarang dalam proses pemeriksaan sengketa ekonomi syariah serta bagaimana tinjauan cita hukum terhadap penanganan sengketa ekonomi syariah tersebut.

\section{METODE PENELITIAN}

Dalam menelusuri, menjelaskan serta menyimpulkan objek pembahasan dalam

\footnotetext{
${ }^{16}$ Retnowulan Sutantio, Iskandar Oeripkartawinata, Hukum Acara Perdata dalam Teori dan Praktek, (Bandung: C.V. Mandar Maju, 1997), hlm. 151.

${ }^{17}$ R. Subekti, Hukum Acara Perdata, (Jakarta: Binacipta, 1981), hlm. 154.

18 V. Harlen, Hukum Acara Perdata dengan Pemahaman Hukum Materiil, (Jakarta: Erlangga, 2015), hlm. 270 .

${ }^{19} \mathrm{https} / / /$ putusan.mahkamahagung.go.id/pengadilan/pta-semarang/direktori/perdata-agama/ekonomisyariah, diakses tanggal 13 Desember 2016.
} 


\section{Mohammad Jamaludin}

penelitian ini, penulis menggunakan metode sebagai berikut:

1. Jenis Penelitian ini masuk dalam penelitian field research (penelitian lapangan/empiris) yang mana penelitian ini menitikberatkan pada hasil pengumpulan data dari informan yang telah ditentukan ${ }^{20}$ yaitu narasumber di Pengadilan Tinggi Agama Semarang.

2. Pendekatan Penelitian yang digunakan dalam penelitian ini adalah pendekatan yuridis empiris atau yuridis sosiologis. ${ }^{21}$

3. Lokasi Penelitian dilakukan di Pengadilan Tinggi Agama Semarang yang beralamatkan di Jalan Hanoman Nomor 18 Semarang 50146. Telp. 024-7600803 Fax. 024-7603866 email: ptasemarang@gmail.com.

4. Sumber Data, mengenai sumber data penelitian ini dibagi menjadi dua jenis, yaitu:

a. Data primer. Dalam penelitian ini, data primer diperoleh dengan menggunakan metode wawancara kepada narasumber di Pengadilan Tinggi Agama Semarang yang kemudian diolah sendiri oleh penulis.

b. Data sekunder. Data sekunder yang digunakan penulis dalam penelitian ini meliputi buku-buku, hasil penelitian yang berwujud laporan, buku harian, dan lain-lain yang membahas tentang penanganan sengketa ekonomi syariah di Pengadilan Tinggi Agama..

\section{HASIL DAN PEMBAHASAN}

Pada pembahasan ini, penulis akan memaparkan tinjauan cita hukum keadilan, kepastian hukum, dan kemanfaatan terhadap penanganan sengketa ekonomi syariah di Pengadilan Tinggi Agama Semarang. Hal ini berbeda dengan Aliran etis yang menyatakan bahwa cita hukum adalah semata-mata untuk mencapai keadilan, atau aliran utilitis yang menyatakan bahwa cita hukum adalah semata-mata untuk menciptakan kemanfaatan (kebahagiaan masyarakat), atau aliran normative-dogmatik yang menyatakan bahwa cita hukum adalah semata-mata untuk menciptakan kepastian hukum, penulis akan menggunakan ketiga cita hukum tersebut secara proposional karena ketiga unsur cita hukum tersebut mempunyai hubungan yang erat dalam menciptakan suatu hukum yang baik.

Penulis hanya akan menganalisis penanganan sengketa ekonomi syariah di Pengadilan Tinggi Agama Semarang yang terkait proses pemeriksaan dan dasar hukum yang digunakan hakim dalam proses pemeriksaan tersebut di Pengadilan Tinggi Agama Semarang, tidak menganalisis penanganan sengketa ekonomi syariah di Pengadilan Tinggi

${ }^{20}$ Lexy J. Meleong, Metodologi Penelitian Kualitatif, (Bandung: RosdaKarya, 2010), hlm. 135.

${ }^{21}$ Penulis memadukan antara pendekatan yuridis (hukum dilihat sebagai norma atau das sollen) karena penulis dalam membahas penelitian ini menggunakan bahan-bahan hukum, seperti peraturan perundangundangan, yurisprudensi, serta bahan hukum dari zaman penjajahan yang hingga kini masih berlaku, dan pendekatan empiris (hukum sebagai kenyataan sosial, kultural atau das sein) karena dalam penelitian ini penulis menggunakan data primer yang diperoleh dari lapangan, yaitu narasumber di Pengadilan Tinggi Agama Semarang. Jadi, pendekatan yuridis empiris dalam penelitian ini maksudnya adalah bahwa dalam menganalisis permasalahan dilakukan dengan cara memadukan bahan-bahan hukum (yang merupakan data sekunder) dengan data primer yang diperoleh dari narasumber di Pengadilan Tinggi Agama Semarang, yaitu terkait fungsi judex facti dalam menangani sengketa ekonomi syariah di Pengadilan Tinggi Agama Semarang. 


\section{Mohammad Jamaludin}

Agama secara umum, karena penanganan sengketa ekonomi syariah hanya membahas tentang tata cara pemeriksaan perkara yang fokusnya pada peran hakim sebagai penentu fakta hukum.

\section{Perspektif Cita Hukum Keadilan terhadap penanganan sengketa ekonomi syariah di Pengadilan Tinggi Agama Semarang}

Pembahasan tentang keadilan merupakan salah satu tujuan hukum yang paling banyak dibicarakan sepanjang perjalanan sejarah filsafat hukum. ${ }^{22}$

Persoalan yang timbul dalam mewujudkan prinsip keadilan adalah nilai abstrak yang perlu perwujudan dalam bentuk norma hukum berupa peraturan perundang undangan sebagai sarana dalam mewujudkan nilai-nilai tersebut dalam penegakan hukum.

Norma hukum yang perkembangannya dipersempit dengan hanya diartikan sebagai undang-undang inilah yang pada umumnya dipergunakan segera melalui aparat penegak hukumnya, sehingga perdebatan tentang hukum sudah tidak ada lagi dalam ranah konsep maupun ide-ide, melainkan sebatas undang-undang mana yang dijadikan pegangan sebagai ketentuan yang berlaku mengikat. ${ }^{23}$

Begitu banyak definisi/teori tentang keadilan yang telah ada. Akan tetapi, menurut hemat penulis, pengertian tentang keadilan yang sesuai dalam mewujudkan cita hukum prinsip keadilan terkait penanganan sengketa ekonomi syariah di Pengadilan Tinggi Agama Semarang adalah pengertian yang diajukan oleh Ulpianus. Menurut Ulpianus, keadilan adalah kehendak untuk memberikan bagian kepada setiap orang haknya. ${ }^{24}$

Dalam aplikasinya, usaha dalam mewujudkan cita hukum keadilan terkait penanganan sengketa ekonomi syariah di pengadilan tingkat banding khususnya di Pengadilan Tinggi Agama Semarang terkendala secara yuridis ${ }^{25}$ di beberapa ketentuan yang samar terkait bagaimana pelaksanaan penanganan sengketa ekonomi syariah di pengadilan tingkat banding. Apakah penanganan sengketa ekonomi syariah di pengadilan tingkat banding diterapkan secara langsung dengan memeriksa para pihak yang berperkara atau penanganan sengketa ekonomi syariah di pengadilan tingkat banding diterapkan dengan cara pemeriksaan berkas perkara (surat-surat).

Dalam Pasal 15 ayat (1) Undang-Undang Nomor 20 Tahun 1947 tentang Pengadilan Peradilan Ulangan dinyatakan:

"Pengadilan Tinggi dalam pemeriksaan ulangan memeriksa dan memutus dengan tiga hakim, jika dianggap perlu, dengan mendengar sendiri kedua belah pihak atau saksi”.

Jika bertitik tolak dari ketentuan tersebut di atas, penanganan sengketa ekonomi syariah di pengadilan tingkat banding dilaksanakan dengan memeriksa secara langsung para pihak yang berperkara, dengan pertimbangan bahwa cara yang demikian lebih efektif karena pengadilan tinggi agama lebih tahu hal-hal apa saja yang hendak diperiksa. Akan tetapi, jika ketentuan tersebut dijalankan, maka akan berseberangan dengan ketentuan lain, seperti ketentuan dalam Pasal 57 ayat (3) Undang-Undang Nomor 7 Tahun 1989 tentang Peradilan

\footnotetext{
22 Darji Darmodiharjo, Shidarta, Pokok-Pokok Filsafat Hukum ..., hlm. 155.

${ }^{23}$ Mahmutarom, Reskontruksi Konsep Keadilan ..., hlm. 199.

${ }^{24}$ I. Dewe Gede Atmadja, Filsafat ..., hlm. 71-72.

${ }^{25}$ Kendala yuridis adalah kendala yang di timbulkan oleh faktor yuridis (hukum) yang mengakibatkan Pengadilan Tinggi Agama Semarang tidak dapat melaksanakan tugas pokok dan fungsinya dengan baik, terutama dalam memberikan pelayanan hukum dan keadilan secara optimal kepada masyarakat pencari
} keadilan sebagaimana mestinya. 


\section{Mohammad Jamaludin}

Agama, dan Pasal 2 ayat (4) Undang-Undang Nomor 48 Tahun 2009 tentang Kekuasaan Kehakiman yang menjadi dasar prinsip hukum sederhana, cepat dan biaya ringan.

Pelaksanaan penanganan sengketa ekonomi syariah di pengadilan tingkat banding dengan memeriksa secara langsung kepada para pihak yang berperkara juga akan bertentangan dengan ketentuan lain dalam Surat Edaran Mahkamah Agung Nomor 2 Tahun 20014 tentang Penyelesaian Perkara di Pengadilan Tingkat Pertama dan Tingkat Banding pada empat Lingkungan Peradilan, bertentangan juga dengan ketentuan dalam Peraturan Mahkamah Agung Nomor 2 Tahun 2009 tentang Biaya Proses Penyelesaian Perkara dan Pengelolaannya pada Mahkamah Agung dan Badan Peradilan yang berada di bawahnya, juga bertentangan dengan Keputusan Ketua Pengadilan Tinggi Agama Semarang Nomor WII-A/2786/HK.00.8/XII/2009 tentang Perkara Banding pada Pengadilan Tinggi Agama Semarang.

Pertentangan-pertentangan tersebut terjadi karena ketika hakim pengadilan tingkat banding berkehendak untuk melakukan pemeriksaan secara langsung kepada para pihak yang berperkara, hal tersebut akan menjadikan beban biaya perkara bertambah banyak, apalagi jika jarak antara tempat tinggal para pihak yang berperkara dan saksi yang akan diperiksa jauh dari Kantor Pengadilan Tinggi Agama Semarang. Belum lagi, jangka waktu penanganan perkara pasti akan bertambah lama. Penulis sependapat dengan apa yang telah dilakukan oleh Hakim Pengadilan Tinggi Agama Semarang, yang mana sampai saat ini belum pernah menerapkan penanganan sengketa ekonomi syariah dengan memeriksa sendiri para pihak yang berperkara atau saksi secara langsung dikarenakan dari semua permohonan banding yang diajukan ke Pengadilan Tinggi Agama Semarang berasal dari pengadilan agama yang jaraknya jauh dari Kantor Pengadilan Tinggi Agama Semarang seperti Pengadilan Agama Kebumen, Purbalingga, Magelang, Surakarta, Pekalongan, Pemalang, Klaten, dan Purworejo. Hal ini penulis rasa lebih berkeadilan daripada tetap memaksakan untuk menerapkan penanganan sengketa ekonomi syariah dengan memeriksa secara langsung para pihak yang berperkara.

Melihat banyaknya ketentuan-ketentuan yang berseberangan ketika penanganan sengketa ekonomi syariah di pengadilan tingkat banding diterapkan dengan cara memeriksa para pihak yang berperkara secara langsung, menurut hemat penulis lebih berkeadilan jika penanganan sengketa ekonomi syariah di pengadilan tingkat banding diterapkan dengan cara memeriksa (melalui) surat-surat (berkas perkara) yang dikirmkan pengadilan agama yang telah memeriksa dan memutus perkara tersebut di tingkat pertama. Penulis sependapat dengan Nunuk Nuswardani yang menyatakan bahwa, tata cara pemeriksaan perkara pada peradilan tingkat banding tidak harus sama seperti peradilan tingkat pertama, karena sebagian duduk perkaranya sudah jelas dan tidak mungkin ada perubahan, seperti duduk perkara yang telah dituangkan secara tertulis dalam acara jawab menjawab (replik duplik). ${ }^{26}$ Pemeriksaan dengan berkas perkara diatur dalam pasal $357 \mathrm{Rv}$ yang menyatakan bahwa:

"Perkara kemudian oleh Hakim Banding yang bersangkutan tanpa banyak proses diputus berdasarkan surat-surat saja, tetapi ia berwenang sebelum menjatuhkan putusan akhir untuk

26 Nunuk Nuswandani, "Wewenang Mahkamah Konstitusi sebagai Judex Facti dalam memutus perselisihan Hasil Pemilihan Umum", Disertasi, tidak diterbitkan, Fakultas Hukum Universitas Airlangga (2007). Dalam Moh. Amir Hamzah, Hukum Acara Perdata ..., hlm. 182.

$\mathbf{2 3}$

Jurnal Al Qardh, 5(1), 14-37

Copyright (C) 2020 by Al-Qardh, p-ISSN 2354-6034; e-ISSN 2599-0187 


\section{Mohammad Jamaludin}

memberikan putusan persiapan atau putusan sela".

Penerapan penanganan sengketa ekonomi syariah di peradilan tingkat banding dengan memeriksa (melalui) surat-surat (berkas perkara) harus diterapkan dengan cara melakukan pemeriksaan ulangan secara menyeluruh terhadap surat-surat (berkas perkara) yang telah dkirimkan oleh peradilan agama yang telah memeriksa dan memutus perkara tersebut pada tingkat pertama. Pemeriksaan tersebut meliputi pemeriksaan terhadap fakta/duduk perkara, gugatan awal (konvesi) dan gugatan balik (rekovensi), penerapan hukum dalam putusan, keberatan-keberatan yang diajukan pembanding, dan surat-surat lain sebagaimana diatur dalam putusan Mahkamah Agung Nomor 951 K/Sip/1973, tanggal 9 Oktober 1975 yang menyatakan:

"Cara pemeriksaan perkara perdata di tingkat banding-pengadilan tinggi yang hanya memeriksa keberatan-keberatan yang diajukan oleh pembanding saja, adalah salah. Seharusnya Majelis Hakim Banding juga melakukan pemeriksaan ulang atas seluruh perkara tersebut, baik faktanya, maupun penerapan hukumnya yang telah diputuskan oleh hakim pertama". 27

Diatur juga dalam putusan Mahkamah Agung RI Nomor 876/Sip/1973 yang menyatakan:

“...permohonan banding oleh penggugat harus diperiksa secara keseluruhan, baik dalam konvensi maupun dalam rekovensi”.

Demikian juga diatur dalam putusan Mahkamah Agung Nomor 194 K/Sip/1973, tanggal 30 November 1976 dinyatakan bahwa:

"Pengadilan Tinggi sebagai Peradilan tingkat banding, dalam memeriksa perkara perdata yang dimohon banding, harus memeriksa dan memberikan putusan perkara tersebut secara keseluruhannya, baik yang konvensi maupun yang rekonvensi yang telah diputus oleh peradilan tingkat pertama".

Dan ketika hakim pengadilan tinggi agama berpendapat ada hal-hal yang memerlukan kejelasan atau untuk menambah kesempurnaan pembuktian, pemeriksaan setempat, pemeriksaan saksi ahli dan sebagainya, hakim dapat melakukan pemeriksaan tambahan yang diperintahkan kepada pengadilan agama yang memeriksa dan memutus pada tingkat pertama sebelum menjatuhkan putusan akhir dengan menuangkannya dalam putusan sela yang di dalamnya berisi perintah untuk melakukan pemeriksaan tambahan dengan merinci hal-hal yang akan diperiksa.

Ketentuan tentang hal tersebut telah diatur dalam putusan Mahkamah Agung Nomor 3136 K/Sip/1983 yang menyatakan bahwa:

“... sesuai ketentuan pasal 15 ayat (1) UU No. 20 Tahun 1947, pengadilan tinggi berwenang melakukan sendiri pemeriksaan tambahan, bahkan cara yang demikian lebih efektif karena pengadilan tinggi lebih tau hal-hal apa saja yang hendak diperiksa, namun jika pengadilan hendak melakukan sendiri pemeriksaan tambahan langsung kepada para pihak harus benarbenar dipertimbangkan faktor biaya yang harus dipikul para pihak. Sehubungan dengan itu, tidak mutlak pelaksanaan pemeriksaan tambahan mesti didelegasikan pengadilan tinggi

${ }^{27}$ Hulman Panjaitan, Kumpulan Kaidah Hukum ..., hlm. 160. 


\section{Mohammad Jamaludin}

kepada pengadilan negeri”.

Penerapan penanganan sengketa ekonomi syariah di Pengadilan Tinggi Agama meliputi pemeriksaan ulang perkara secara keseluruhan, dari awal pengajuan gugatan oleh penggugat, perumusan fakta sampai penerapan hukum di dalam putusan yang terdapat dalam surat-surat yang dikirimkan oleh pengadilan agama yang memeriksa dan memutus pada tingkat pertama harus dijalankan secara konsisten. Pemeriksaan juga meliputi keberatankeberatan yang diajukan oleh pembanding, secara konvensi maupun rekovensi. Dan apabila surat-surat yang dikirim oleh pengadilan agama yang memeriksa dan memutus pada tingkat pertama dirasa kurang, dan hakim berpendapat ada hal-hal yang memerlukan kejelasan atau untuk menambah kesempurnaan pembuktian, pemeriksaan setempat, pemeriksaan saksi ahli dan sebagainya, hakim dapat melakukan pemeriksaan tambahan yang diperintahkan kepada pengadilan tingkat pertama sebelum menjatuhkan putusan akhir dengan menuangkannya dalam putusan sela yang di dalamnya berisi perintah untuk melakukan pemeriksaan tambahan dengan merinci hal-hal yang akan diperiksa.

Apabila penanganan sengketa ekonomi syariah tersebut di atas diterapkan sebagai prinsip hukum secara konsisten, maka akan memenuhi cita hukum keadilan yang menjadi tujuan utama dari pembentukan hukum.

Akan tetapi, walaupun ketentuan terkait pelaksanaan penanganan sengketa ekonomi syariah di Pengadilan Tinggi Agama Semarang telah menjadi ketentuan yang telah digariskan dalam SOP (Standard Operating Procedure/Standar Prosedur Operasional), ternyata penanganan tersebut belum berjalan sepenuhnya. Penulis berpendapat seperti ini karena, dalam salah satu putusan Pengadilan Tinggi Agama Semarang Nomor 160/Pdt.G/2014/PTA.Smg, hakim masih mengutip yurisprudensi Mahkamah Agung Nomor 1995 Nomor 247 K/Sip/1995 yang menyatakan bahwa:

"Menimbang, bahwa selanjutnya Pengadilan Tinggi Agama berpendapat, keberatan keberatan yang diajukan oleh para Tergugat/Para Pembanding tidaklah perlu dipertimbangkan lebih lanjut karena sesuai dengan yurisprudensi Mahkamah Agung RI tanggal 06 April 1955 Nomor 247 K/Sip/1955, yang menyatakan: "Bahwa Hakim Banding tidak wajib meninjau satu persatu dalil yang termuat dalam suatu memori banding dan juga tidak wajib meninjau satu persatu segala pertimbangan Hakim Tingkat Pertama“. ${ }^{28}$

Pertimbangan untuk menjadikan yurisprudensi tersebut menjadi dasar pertimbangan hukum hakim penulis rasa kurang tepat, karena hal tersebut dirasa tidak berkeadilan, walaupun hakim tidak terikat pada putusan yurisprudensi tersebut karena Indonesia tidak menganut asas "The Bidding Force of Precedent ${ }^{29 "}$ "Seharusnya, sebagaimana yang penulis paparkan sebelumnya, Hakim Pengadilan Tinggi Agama Semarang harus memeriksa ulang seluruh perkara dari awal pengajuan gugatan oleh penggugat, perumusan fakta sampai penerapan hukum di dalam putusan, dan juga mempertimbangkan keberatan-keberatan yang diajukan oleh para tergugat/pembanding dalam memori banding, karena hal tersebut merupakan berkas perkara yang harus diperiksa hakim kaitannya dengan fungsi judex facti pengadilan tinggi agama dalam memeriksa ulang perkara secara menyeluruh.

Yurisprudensi yang dijadikan dasar hukum pertimbangan hakim di atas juga

28 Salinan Putusan Nomor 160/Pdt.G/2014/PTA.Smg., hlm. 7-8. Bisa diakses di https://putusan.mahkamahagung.go.id/putusan/19bfa3cbae6bc262936d4563ae2c7b2f.

${ }^{29}$ Asas ini menyatakan bahwa hakim bebas memilih antara meninggalkan yurisprudensi atau menggunakannya. 


\section{Mohammad Jamaludin}

berseberangan dengan yurisprudensi lain, yaitu yurisprudensi Mahkamah Agung Nomor 951 K/Sip/1973 yang menyatakan bahwa:

"...cara pemeriksaan dalam tingkat banding, tidak hanya memperhatikan keberatankeberatan yang diajukan oleh pembanding saja, cara demikian adalah salah; seharusnya dalam tingkat banding, hakim mesti memeriksa ulang kembali perkara dalam keseluruhan baik yang mengenai fakta-fakta maupun mengenai penerapan hukum..."

Dalam yurisprudensi kedua ini diatur bahwa, pemeriksaan ulang harus tetap dilakukan oleh majelis hakim walaupun tidak ada permintaan langsung dari Para Pembanding dalam memori banding.

Melihat ketentuan-ketentuan dalam yurisprudensi Mahkamah Agung yang saling berseberangan di atas, hakim sebagai penegak hukum mempunyai posisi yang penting sebagai pemutus aturan perundang-undangan mana yang akan digunakan dan dijadikan pedoman dalam menyelesaikan sengketa yang lebih mendekati kebenaran dan keadilan. Hal seperti ini akan sering dihadapi oleh hakim khususnya dalam proses pemeriksaan perkara di persidangan. Oleh karenanya, hakim sebagai pemutus perkara harus mampu memutuskan dengan putusan yang diyakini sebagai kebenaran dan mencerminan keadilan, karena kewajiban hakim dalam memutus perkara harus mampu menggali dan menemukan nilainilai keadilan yang hidup dan berkembang dalam masyarakat. ${ }^{30}$

Dalam proses pemeriksaan perkara di peradilan tingkat banding, hakim seyogyanya mempertimbangkan semua berkas perkara yang dikirimkan oleh peradilan tingkat pertama yang telah memeriksa dan memutus perkara, termasuk juga mempertimbangkan satu persatu dalil yang ada di dalam memori banding, dan pertimbangan hakim tingkat pertama agar Hakim Pengadilan Tinggi Agama Semarang dapat memahami dengan baik fakta yang sebenarnya terjadi, dan apa yang membuat para pembanding merasa keberatan dan dirugikan atas putusan pengadilan tingkat pertama yang memeriksa dan memutus pada tingkat pertama, yang pada akhirnya menjadikan para pembanding mengajukan permohonan banding ke Pengadilan Tinggi Agama Semarang. Jika hal ini dilakukan secara konsisten, akan terwujud cita hukum keadilan dalam pelaksanaan penanganan sengketa ekonomi syariah di Pengadilan Tinggi Agama Semarang.

Walaupun konsep adil sulit diukur bagi para pihak yang bersengketa, karena adil menurut satu pihak, belum tentu adil menurut pihak lain. Akan tetapi hakim mempunyai tugas untuk menegakkan keadilan sebagaimana diatur dalam pasal 5 Undang-Undang Nomor 48 Tahun 2009 tentang Kekuasaan Kehakiman yang menyatakan:

“(1) Hakim dan hakim konstitusi wajib menggali, mengikuti, dan memahami nilai-nilai hukum dan rasa keadilan yang hidup dalam masyarakat. (2) Hakim dan hakim konstitusi harus memiliki integritas dan kepribadian yang tidak tercela, jujur, adil, profesional, dan berpengalaman di bidang hukum.

${ }^{30}$ Pasal 27 Undang-Undang Nomor 14 Tahun 1970 tentang Pokok-Pokok Kekuasaan Kehakiman. Sedangkan dalam Undang-Undang Nomor 4 Tahun 2004 tentang Kekuasaan Kehakiman sebagai pengganti Undang-Undang Nomor 14 Tahun 1970 diatur dalam pasal 25 dengan teks yang berbeda, meskipun kandungan maksudnya dapat berarti sama. Secara lengkap pasal 25 ayat (1): "Segala putusan pengadilan selain harus memuat alasan dan dasar putusan tersebut, memuat pula pasal tertentu dari peraturan perundang-undangan yang bersangkutan atau sumber hukum tak tertulis yang dijadikan dasar untuk mengadili”. 


\section{Mohammad Jamaludin}

\section{Perspektif Cita Kepastian Hukum terhadap penanganan sengketa ekonomi syariah di Pengadilan Tinggi Agama Semarang}

Pengadilan di lingkungan Peradilan Agama adalah lembaga yang berwenang secara absolut dalam menyelesaikan sengketa ekonomi syariah. Ketentuan tentang hal tersebut diatur dalam Undang-Undang Nomor 7 Tahun 1989 tentang Peradilan Agama yang telah diubah dengan disahkannya Undang-Undang Nomor 3 Tahun 2006 dan Undang-Undang Nomor 50 Tahun 2009. Penguatan kewenangan ini diperkuat dengan disahkannya Putusan Mahkamah Konstitusi Nomor 93/PUU-X/2012 yang menjadikan pengadilan dalam lingkungan peradilan agama menjadi satu-satunya yang berwenang dalam menyelesaikan sengketa ekonomi syariah secara litigasi.

Akan tetapi, ketentuan tersebut tidak dibarengi dengan peraturan perundangundangan yang secara khusus mengatur tentang penyelesaian sengketa ekonomi syariah di Lingkungan Peradilan Agama, khususnya di Pengadilan Tinggi Agama. Ketiadaan instrument hukum materiil dan formil dalam menangani perkara ekonomi syariah ini mengakibatkan ketidakpastian hukum dan disparitas putusan antara satu hakim dengan lainnya.

Seharusnya, ketika sebuah ketentuan atau kewenangan baru diamanatkan ke sebuah lembaga peradilan, seyogyanya diatur pula ketentuan perihal tata cara pemeriksaan atau lebih dikenal dengan hukum acara dalam menyelesaikan sengketa tersebut. Karena, ketika berbicara tentang bekerjanya dan tercapainya tunjuan hukum dibutuhkan tata aturan atau legalitas dalam pencapaian kepastian hukum.

Dari penelusuran yang penulis lakukan, baik penelitian yang penulis lakukan di Pengadilan Tinggi Agama Semarang, ataupun dari literatur-literatur yang penulis baca, setidaknya ada tiga kendala yuridis yang penulis temukan terkait perwujudan cita kepastian hukum dalam pelaksanaan penanganan sengketa ekonomi syariah di Pengadilan Tinggi Agama khususnya di Pengadilan Tinggi Agama Semarang.

Beberapa kendala yuridis yang menimbulkan ketidakpastian hukum dalam penyelesaian sengketa ekonomi syariah di Pengadilan Tinggi Agama adalah: Pertama, kendala yuridis terkait tidak adanya peraturan perundang-undangan yang khusus mengatur tentang penegakan hukum acara perdata ataupun ketentuan perihal tata cara pemeriksaan sengketa ekonomi syariah di peradilan tingkat banding.

Peradilan tingkat pertama dan pengadilan tingkat banding merupakan peradilan judex facti, akan tetapi dasar hukum acara perdata yang digunakan di kedua peradilan tersebut berbeda. Hukum acara perdata yang digunakan dalam peradilan pertama (Peradilan Agama) masih mengikuti hukum acara perdata peradilan dalam lingkungan peradilan umum ${ }^{31}$, yaitu Het Herziene Indonesich Reglement/Reglemen Indonesia Baru (HIR) dan Reglement op de Buitengewesten (RBg) ditambah dengan Peraturan Mahkamah Agung Nomor 14 Tahun 2016 tentang Tata Cara Penyelesaian Perkara Ekonomi Syariah, sedangkan di tingkat banding (Pengadilan Tinggi Agama) hukum acara perdata diatur dalam Het Herziene Indonesich Reglement/Reglemen Indonesia Baru (HIR) dan Undang-Undang Nomor 20 Tahun 1947 tentang Pengadilan Peradilan Ulangan, dan tidak diatur dalam Peraturan Mahkamah Agung Nomor 14 Tahun 2016 tentang Tata Cara Penyelesaian Perkara Ekonomi Syariah.

Walaupun telah penulis sebutkan bahwa hukum acara perdata pada peradilan banding

${ }^{31}$ Pasal 54 Undang-Undang Nomor 7 Tahun 1989 tentang Peradilan Agama. 


\section{Mohammad Jamaludin}

diatur dalam Het Herziene Indonesich Reglement/Reglemen Indonesia Baru (HIR), UndangUndang Nomor 20 Tahun 1947 tentang Pengadilan Peradilan Ulangan dan di RBg, akan tetapi dalam aturan tersebut tidak ditemukan ketentuan tentang tata cara pemeriksaan perkara di tingkat banding. Dalam HIR, Undang-Undang Nomor 20 Tahun 1947 dan RBg hanya mengatur tentang administrasi justisial saja. Oleh karenanya, untuk mengisi kekosongan hukum acara perdata di pengadilan tingkat banding, Hakim Pengadilan Tinggi Agama khususnya Pengadilan Tinggi Agama Semarang menggunakan ketentuan dalam Pasal 357 Rv untuk proses pemeriksaan perkara ekonomi syariah, dengan pertimbangan karena penerapannya dianggap sangat bermanfaat, disamping itu tidak memberatkan para pihak yang berperkara dalam hal biaya penanganan perkara yang harus dikeluarkan dan waktu penanganan perkara yang berlangsung lebih singkat.

Menurut M. Amir Hamzah, Penerapan Rv pada praktek peradilan tingkat banding tidak berlandaskan filosofis yang kuat karena tidak memperhatikan hakikat peradilan tingkat banding merupakan peradilan judex facti tingkat dua. ${ }^{32}$ Hukum acara perdata yang mengatur tentang tata cara pemeriksaan perkara pada peradilan tingkat banding berlaku ketentuan yang terdapat dalam Rv, hal ini disebabkan penunjukan berlakunya Pasal 357 Rv oleh Pasal 204 $\mathrm{RBg}^{33}$.

Terbitnya Peraturan Mahkamah Agung Nomor 14 Tahun 2016 tentang Tata Cara Penyelesaian Sengketa Ekonomi Syariah yang disebut-sebut akan menjadi Kompilasi Hukum Acara Ekonomi Syariah (KHAES), dan menjadi pelengkap dari Kompilasi Hukum Ekonomi Syariah (KHES) yang diatur Undang-Undang Nomor 2 Tahun 2008 tentang Kompilasi Hukum Ekonomi Syariah, ternyata juga tidak mengatur terkait tata cara pemeriksaan sengketa ekonomi syariah di pengadilan tinggi agama.

Jika dipelajari lebih mendalam, penerbitan Peraturan Mahkamah Agung Nomor 14 Tahun 2016 sebenarnya dilatarbelakangi karena dalam ketentuan hukum acara penanganan sengketa ekonomi syariah baik dalam HIR, RBg maupun berbagai peraturan perundangundangan yang terkait tidak membedakan tata cara pemeriksaan antara objek materiil yang jumlahnya besar dengan yang berjumlah kecil, yang mengakibatkan pada lamanya proses penyelesaian perkara ekonomi syariah meskipun sengketa tersebut bersifat sederhana dan nilai objek sengketanya kecil, ${ }^{34}$ oleh karena itu, diterbitkan peraturan yang mengatur tentang hal tersebut.

Akan tetapi sangat disayangkan, bahwa peraturan yang dijadikan sebagai Kompilasi Hukum Acara Ekonomi Syariah yang telah dinanti-nanti kehadirannya hanya mengatur tentang tata cara pemeriksaan perkara ekonomi syariah di pengadilan tingkat pertama tanpa mengatur tentang tata cara pemeriksaan perkara ekonomi syariah di pengadilan tingkat banding, yang mana menurut hemat penulis, pengaturan khusus tentang tata cara pemeriksaan perkara ekonomi syariah pada peradilan tingkat banding tetap sangat dibutuhkan demi terciptanya kepastian hukum bagi setiap orang yang turut terlibat dalam

${ }^{32}$ Moh. Amir Hamzah, Hukum Acara Perdata ..., hlm. 157.

${ }^{33}$ Pasal 204 RBg menyatakan bahwa: "terhadap pemeriksaan pada tingkat banding berlaku ketentuanketentuan yang tercantum dalam Titel ke VII Buku pertama Reglemen Acara Perdata". Yang dimaksud dengan reglemen acara perdata adalah reglement of rechtsvordering (Rv). Rv berlaku karena ditunjuk oleh Pasal 204 $\mathrm{RBg}$, sedangkan RBg yang mengatur tentang banding merupakan ketentuan yang dinyatakan masih berlaku oleh Undang-Undang Darurat Nomor 1 Tahun 1951.

${ }^{34}$ Pokja Laporan Tahunan MARI, Laporan Tahunan 2016 Mahkamah Agung Republik Indonesia, (Jakarta: Mahkamah Agung RI, 201), hlm. 10. Bisa diakses di http://www.pembaruanperadilan.net/v2/unduhdokumen/laptah-ma/ 


\section{Mohammad Jamaludin}

proses hukum.

Dalam Peraturan Mahkamah Agung Nomor 14 Tahun 2016 diatur bahwasanya perkara ekonomi syariah dapat diajukan dalam bentuk gugatan sederhana ${ }^{35}$ atau dengan acara biasa. Agar gugatan dapat diajukan dengan cara sederhana harus memenuhi beberapa ketentuan, di antaranya: nilai gugatan paling banyak Rp. 200.000.000, domisili penggugat dan tergugat harus di wilayah hukum yang sama, jumlah para pihak (penggugat dan tergugat) masing-masing tidak boleh dari satu (kecuali punya kepentingan hukum yang sama), alamat tergugat harus diketahui, pendaftaran perkara menggunakan blanko gugatan, pengajuan bukti-bukti harus bersamaan dengan pendaftaran perkara. Apabila gugatan yang akan diajukan dengan cara sederhana tidak memenuhi persyaratan tersebut, maka gugatan tersebut akan diajukan dalam bentuk gugatan dengan acara biasa.

Dalam Peraturan Mahkamah Agung Nomor 14 Tahun 2016 ini di samping mengatur ketentuan yang positif terkait tata cara pemeriksaan sengketa ekonomi syariah pada peradilan tingkat pertama, akan tetapi juga mempunyai beberapa konsekwensi, di antaranya: tidak terdapat mediasi, pemeriksaan dan pemutusan dilakukan oleh hakim tunggal, terdapat pemeriksaan pendahuluan, kehadiran para pihak wajib disetiap persidangan secara langsung (meskipun punya kuasa hukum), konsekwensi ketidakhadiran penggugat pada sidang pertama tanpa alasan yang sah adalah gugatan dinyatakan gugur, pemeriksaan perkara hanya gugatan dan jawaban, upaya hukum yang dapat ditempuh adalah keberatan (tidak ada banding, kasasi ataupun peninjauan kembali) yang diajukan 7 hari sejak putusan diucapkan/diberitahukan. ${ }^{36}$

Fakta hukum tentang ketiadaan pengaturan tata cara pemeriksaan perkara ekonomi syariah pada peradilan tingkat banding ini merupakan kekosongan hukum acara perdata dalam peradilan tingkat banding. Kekosongan hukum acara di pengadilan tingkat banding ini mengakibatkan hilangnya jaminan tentang adanya kepastian hukum bagi setiap orang yang turut terlibat dalam proses hukum, karena pada dasarnya hukum acara bertujuan memperhatikan masalah-masalah keadilan yang mendasar (fundamental), jaminan ini diberikan karena sistem hukum didasarkan atas pemikiran bahwa terdapat batas kekuasaan pemerintah, karena meskipun pemerintah bertindak sewenang-wenang, sehingga seseorang yang digugat dalam perkara yang sangat serius, sekalipun harus menjalani persidangan yang diatur oleh seperangkat aturan, memperoleh jaminan hukum.

Kedua, terkait ketidaktegasan Mahkamah Agung dalam menjelaskan perbedaan konsep antara "Pemeriksaan Ulangan" di dalam Pasal 15 ayat (1) Undang-Undang Nomor 20 tahun 1947 tentang Pengadilan Peradilan Ulangan yang menyatakan: "Pengadilan Tinggi dalam pemeriksaan ulangan memeriksa dan memutuskan dengan Tiga Hakim, jika dipandang perlu, dengan mendengar sendiri kedua belah pihak atau saksi”, dengan konsep "Pemeriksaan Tambahan" dalam putusan Mahkamah Agung Nomor 3136 K/Sip/1983 yang menyatakan bahwa: "sesuai ketentuan Pasal 15 ayat (1) UU No. 20 Tahun 1947, pengadilan tinggi berwenang melakukan sendiri pemeriksaan tambahan".

Mahkamah Agung tidak menjelaskan lebih lanjut pengertian konsep pemeriksaan ulangan dengan pemeriksaan tambahan di dalam kedua peraturan tersebut, apakah keduanya

35 Penyelesaian Gugatan Sederhana adalah tata cara pemeriksaan di persidangan terhadap gugatan perdata dengan nilai gugatan materiil paling banyak Rp. 200.000.000 yang diselesaikan dengan tata cara dan pembuktian sederhana.

36 http://badilag.mahkamahagung.go.id/seputar-ditjen-badilag/seputar-ditjen-badilag/membedahperma-tata-cara-penyelesaian-perkara-ekonomi-syariah, diakses tanggal 12 Februari 2017. 


\section{Mohammad Jamaludin}

memiliki kesamaan konsep atau berbeda, mahkamah agung juga tidak menjabarkan lebih lanjut tentang bagaimana proses pemeriksaan yang dilakukan pengadilan tinggi agama jika melakukan pemeriksaan ulangan atau pemeriksaan tambahan. Hal ini menjadi penting karena ketentuan di dalam peraturan yang multitafsir bisa mengakibatkan putusan tidak mempunyai kepastian hukum.

Ditambah lagi, ketentuan dalam Pasal 15 ayat (1) yang bersifat subjektif dan tidak adil. Dalam Pasal tersebut dinyatakan: "Pengadilan Tinggi dalam pemeriksaan ulangan memeriksa dan memutuskan dengan tiga Hakim, jika dipandang perlu, dengan mendengar sendiri kedua belah pihak atau saksi". Kalimat "jika dipandang perlu dengan mendengar sendiri kedua belah pihak atau saksi" menimbulkan kekaburan jika dihubungkan dengan bunyi Pasal 6 ayat yang menyatakan bahwa:

"Dari putusan-putusan Pengadilan Negeri di Jawa dan Madura tentang perkara perdata, yang tidak ternyata bahwa besarnya harga gugat ialah seratus rupiah atau kurang, oleh salah satu dari pihak-pihak (partijen) yang berkepentingan dapat diminta, supaya pemeriksaan perkara diulangi oleh Pengadilan Tinggi yang berkuasa dalam daerah hukum masingmasing".

Pada Pasal 6 ini, dijelaskan bahwa tidak ada syarat apapun agar Pengadilan tingkat banding memeriksa ulang secara keseluruhan.

Ketiga, terkait yurisprudensi Mahkamah Agung yang bertentangan atau bertolak belakang antara satu dan lainnya, di antaranya: dalam putusan Mahkamah Agung Nomor $247 \mathrm{~K} / \mathrm{Sip} / 1953$, tanggal 6 April 1955 dinyatakan:

"Hakim banding tidak wajib meninjau satu persatu dali-dalil yang termuat dalam memori banding dan juga tidak wajib meninjau satu persatu segala pertimbangan dari hakim pertama".

Putusan ini bertolak belakang/bertentangan dengan Putusan Mahkamah Agung Nomor 112 K/Sip/1955, tanggal 11 April 1956 yang menyatakan:

"Keberatan-keberatan Pembanding yang tercantum dalam memori banding, wajib dipertimbangkan oleh pengadilan tinggi dalam putusannya".

Jika dilihat secara seksama, pertentangan terjadi antara kedua putusan di atas, yang mana pada putusan pertama tidak mewajibkan hakim Pengadilan Tinggi untuk meninjau satu-persatu dalil yang termuat dalam memori banding, akan tetapi pada putusan kedua menyatakan bahwa hakim Pengadilan Tinggi wajib mempertimbangkan keberatankeberatan Pembanding yang tercantum dalam memori banding. Tidak dijelaskan pula bagaimana kedudukan kedua putusan tersebut, apakah putusan kedua meniadakan putusan yang pertama/lex posterior derogate legi priori (dalam artian putusan kedua yang dikeluarkan Mahkamah Agung menghapuskan putusan yang pertama), atau semua menjadi kewenangan hakim pengadilan tinggi dalam menafsirkan putusan tersebut.

Seharusnya, yurisprudensi yang merupakan sumber hukum formal yang akan diikuti dan dipergunakan oleh hakim berikutnya sebagai sumber hukum untuk memutus sebuah perkara tidak bertentangan satu sama lain, karena hal ini akan mengakibatkan ketidakpastian hukum dalam penanganan perkara, khususnya perkara ekonomi syariah.

Beberapa kendala yuridis terkait kendala yuridis terkait tidak adanya peraturan perundang-undangan yang khusus mengatur tentang penegakan hukum acara perdata ataupun ketentuan perihal tata cara pemeriksaan sengketa ekonomi syariah, ketidak tegasan Mahkamah Agung dalam menjelaskan perbedaan konsep antara "pemeriksaan ulangan" dalam pasal 6 dengan konsep "pemeriksaan tambahan" dalam pasal 15 Undang-Undang

$\overline{\mathbf{3 0}}$

Jurnal Al Qardh, 5(1), 14-37

Copyright (C) 2020 by Al-Qardh, p-ISSN 2354-6034; e-ISSN 2599-0187 


\section{Mohammad Jamaludin}

Nomor 20 tahun 1947 tentang Pengadilan Peradilan Ulangan, ditambah lagi dengan yurisprudensi Mahkamah Agung yang bertentangan atau bertolak belakang antara satu dan lainnya di atas menjadikan ketidakpastian hukum dalam dalam pelaksanaan fungsi judex facti di Pengadilan Tinggi Agama Semarang dalam menangani sengketa ekonomi syariah.

Kepastian di sini berarti kejelasan norma sehingga dapat dijadikan pedoman bagi para pihak yang dikenakan peraturan ini. Pengertian kepastian tersebut dapat dimaknai bahwa ada kejelasan dan ketegasan terhadap penegakan hukum dalam penyelesaian sengketa ekonomi syariah yang terjadi dan tidak menimbulkan banyak salah tafsir.

Kepastian hukum adalah jaminan bahwa hukum dijalankan seperti seharusnya, dan yang berhak menurut hukum dapat memperoleh haknya dan putusan yang dihasilkan dapat dilaksanakan.

Walaupun terdapat beberapa kendala yuridis terkait tidak adanya peraturan perundang-undangan yang secara khusus mengatur tentang penegakan hukum acara perdata ataupun ketentuan perihal tata cara pemeriksaan sengketa ekonomi syariah, salah satu usaha yang perlu diapresiasi atas usaha yang telah dilakukan oleh Pengadilan Tinggi Agama Semarang untuk mengisi kekosongan tersebut guna mewujudkan cita kepastian hukum adalah dengan disusunnya Standard Operating Procedure/Standar Prosedur Operasional sebanyak 57 SOP, yang mana semua SOP tersebut mengatur setiap kegiatan yang ada di Pengadilan Tinggi Agama Semarang yang meliputi tugas-tugas yang dilaksanakan oleh seluruh aparatur Pengadilan Tinggi Agama Semarang dari mulai pimpinan, hakim, pejabat struktural eselon II, III dan IV, pejabat fungsional panitera pengganti sampai kepada staf, dan juga mengatur terkait prosedur operasional penerimaan perkara, pemeriksaan perkara dan putusan akhir, putusan sela, sampai dengan pengiriman bundel A dan putusan akhir ke pengadilan tingkat pertama. Disusunnya SOP ini sebagai penyesuaian dengan format yang ada dalam Peraturan Menteri Pendayagunaan Aparatur Negara Reformasi Birokrasi Nomor 35 Tahun 20012 dan Peraturan Sekertaris Mahkamah Agung RI Nomor 002 Tahun 2012.

Upaya lain yang dilakukan Pengadilan Tinggi Agama guna mewujudkan cita kepastian hukum adalah dengan membentuk Majelis Ekonomi Syariah pada tahun 2015 yang khusus memeriksa dan mengadili perkara ekonomi syariah. Pembentukan majelis hakim ekonomi tersebut dilatar belakangi karena tidak semua hakim tinggi memahami secara mendalam tentang perkara ekonomi syariah, diperlukan hakim tinggi yang memiliki kompetensi dan terlatih yang mempunyai pemahaman yang lebih dan mendalam dalam menangani perkara yang memerlukan keahlian khusus seperti perkara ekonomi syariah.

\section{Tinjauan Cita Hukum Kemanfaatan terhadap Penanganan Sengketa Ekonomi} Syariah di Pengadilan Tinggi Agama Semarang

Disamping kedua cita hukum yang telah penulis paparkan sebelumnya, terdapat satu lagi cita hukum yang menjadi unsur penting dalam penegakan hukum, yaitu kemanfataan.

Dalam analisis ini, penulis mendefiniskan kemanfaatan sebagai kebahagiaan yang didapatkan oleh para pencari keadilan/pihak yang bersengketa, yaitu biaya yang ringan, cepatnya proses penyelesaian sengketa, dan yang terpenting adalah sengketa tersebut dapat memenuhi apa yang mereka harapkan, yaitu penyelesaian yang memuaskan.

Cita hukum kemanfaatan didasarkan pada prinsip hukum acara sederhana, cepat dan biaya ringan yang diatur dalam Pasal 57 ayat (3) Undang-Undang Nomor 7 Tahun 1989 dan Pasal 2 ayat (4) Undang-Undang Nomor 4 Tahun 2009 Kekuasaan Kehakiman yang menyatakan bahwa:

"Peradilan dilakukan dengan sederhana, cepat, dan biaya ringan". 


\section{Mohammad Jamaludin}

Untuk dapat menganalisis cita hukum kemanfaatan terkait penanganan sengketa ekonomi syariah di Pengadilan Tinggi Agama Semarang, penulis sajikan jangka waktu penanganan dan biaya perkara di Pengadilan Tinggi Agama Semarang dalam bentuk tabel berikut ini:

\begin{tabular}{|c|c|c|c|c|}
\hline No & No. Perkara & $\begin{array}{l}\text { Jangka Waktu } \\
\text { Penanganan Perkara }\end{array}$ & Hari & $\begin{array}{l}\text { Biaya } \\
\text { Perkara }\end{array}$ \\
\hline 1 & 152/Pdt.G/2014/PTA.Smg & $\begin{array}{l}21 \text { April } 2014 \text { - } 18 \text { September } \\
2014\end{array}$ & 151 & $150.000,-$ \\
\hline 2 & $\begin{array}{l}\text { 160/Pdt.G/2014/PTA.Smg } \\
\text { Sela }\end{array}$ & 19 Mei 2014 - 21 Agustus 2014 & \multirow[t]{2}{*}{191} & \multirow[t]{2}{*}{$150.000,-$} \\
\hline 3 & 160/Pdt.G/2014/PTA.Smg & 25 Nopember 2014 & & \\
\hline 4 & 168/Pdt.G/2015/PTA.Smg & 12 Mei 2015 - 30 September 2015 & 142 & 150.000,- \\
\hline 5 & 129/Pdt.G/2015/PTA.Smg & 30 Januari 2015 - 13 Agustus 2015 & 196 & $150.000,-$ \\
\hline 6 & 214/Pdt.G/2015/PTA.Smg & 1 Juni 2015 - 10 Desember 2015 & 193 & $150.000,-$ \\
\hline 7 & 241/Pdt.G/2015/PTA.Smg & $\begin{array}{l}10 \text { Agustus } 2015 \text { - } 10 \text { Desember } \\
2015\end{array}$ & 123 & $150.000,-$ \\
\hline 8 & 263/Pdt.G/2015/PTA.Smg & $\begin{array}{l}17 \text { Nopember } 2015 \text { - } 5 \text { Januari } \\
2016\end{array}$ & 50 & $150.000,-$ \\
\hline 9 & 3/Pdt.G/2016/PTA.Smg & 6 Nopember 2015 - 1 Maret 2016 & 117 & $150.000,-$ \\
\hline 10 & 85/Pdt.G/2016/PTA.Smg & 20 Januari 2016 - 31 Mei 2016 & 133 & $150.000,-$ \\
\hline 11 & 93/Pdt.G/2016/PTA.Smg & 4 April 2016 - 24 Juni 2016 & 88 & $150.000,-$ \\
\hline 12 & 162/Pdt.G/2016/PTA.Smg & 14 Juni 2016 - 30 Agustus 2016 & 78 & $150.000,-$ \\
\hline 13 & 183/Pdt.G/2016/PTA.Smg & 11 juli $2016-12$ Oktober 2016 & 94 & $150.000,-$ \\
\hline 14 & 226/Pdt.G/2016/PTA.Smg & $\begin{array}{l}13 \text { September } 2016 \text { - } 18 \text { Desember } \\
2016\end{array}$ & 67 & $150.000,-$ \\
\hline 15 & 172/Pdt.G/2016/PTA.Smg & 24 Juni 2016 - 1 September 2016 & 70 & $150.000,-$ \\
\hline
\end{tabular}

Jika dilihat dari tabel di atas, pelaksanaan penanganan sengketa ekonomi syariah di Pengadilan Tinggi Agama Semarang sebagian besar telah sesuai dengan cita hukum kemanfaatan yang didasarkan pada prinsip hukum acara sederhana, cepat dan biaya ringan yang diatur dalam Pasal 57 ayat (3) Undang-Undang Nomor 7 Tahun 1989 dan Pasal 2 ayat (4) Undang-Undang Nomor 48 Tahun 2009.

Penanganan sengketa ekonomi syariah di Pengadilan Tinggi Agama Semarang yang telah sesuai dengan cita hukum kemanfaatan adalah terkait biaya perkara banding yang diatur dalam Peraturan Mahkamah Agung Nomor 2 Tahun 2009 tentang Biaya Proses Penyelesaian Perkara dan Pengelolaannya pada Mahkamah Agung dan Badan Peradilan yang berada di bawahnya yang selanjutnya melahirkan Keputusan Ketua Pengadilan Tinggi Agama Semarang Nomor WII-A/2786/HK.00.8/XII/2009 tentang Perkara Banding pada Pengadilan Tinggi Agama Semarang. Karena jika dilihat dari kelima belas perkara ekonomi syariah yang telah diputus oleh Hakim Pengadilan Tinggi Agama Semarang, biaya perkara yang harus dikeluarkan pihak yang berperkara telah sesuai dengan yang digariskan dalam Peraturan Mahkamah Agung Nomor 2 Tahun 2009 dan juga telah sesuai dengan ketentuan 


\section{Mohammad Jamaludin}

dalam Keputusan Ketua Pengadilan Tinggi Agama Semarang Nomor WIIA/2786/HK.00.8/XII/2009, yaitu sebesar Rp. 150.000,--

Untuk penanganan sengketa ekonomi sayariah di Pengadilan Tinggi Agama Semarang yang belum sesuai dengan cita hukum kemanfaatan adalah terkait jangka waktu penanganan perkara. Ketidaksesuaian tersebut karena dalam Surat Edaran Mahkamah Agung Nomor 6 Tahun 1992 sebagaimana telah diubah dengan Surat Edaran Mahkamah Agung Nomor 2 Tahun 2014 tentang Penyelesaian Perkara di Pengadilan Tingkat Pertama dan Tingkat Banding pada empat Lingkungan Peradilan dinyatakan bahwa:

"Penyelesaian perkara pada Pengadilan Tingkat Banding paling lambat dalam waktu tiga bulan, ketentuan waktu ini termasuk penyelesaian minutasi”.

Pada praktik yang sudah berjalan, jangka waktu yang dibutuhkan untuk penanganan perkara ekonomi syariah di Pengadilan Tinggi Agama Semarang beragam. Ada yang kurang dari ketentuan yang telah diatur dalam Surat Edaran Mahkamah Agung Nomor 2 Tahun 2014 yaitu kurang dari 90 hari, dan ada yang melebihi dari ketentuan tersebut. Dan kisaran jangka waktu penanganan perkara di Pengadilan Tinggi Agama Semarang adalah 50 hari sampai dengan 196 hari.

\section{KESIMPULAN}

Dari pembahasan tentang penanganan sengketa ekonomi syariah perspektif cita hukum di Pengadilan Tinggi Agama Semarang di atas, maka dapat diambil beberapa kesimpulan yaitu:

1. Mekanisme penanganan sengketa ekonomi syariah di Pengadilan Tinggi Agama Semarang meliputi:

a. Proses administrasi yustisial, yaitu pengajuan permohonan banding, pembayaran biaya banding dan pemeriksaan berkas perkara pemohon banding. Setelahnya panitera memberitahukan permohonan banding kepada terbanding, dilanjutkan dengan melihat, mempelajari dan meneliti berkas perkara (inzage) oleh pembanding dan terbanding. Setelah semua berkas perkara banding lengkap selanjutnya berkas dikirim ke Ketua Pengadilan Tinggi Agama, lalu berkas perkara diserahkan kepada majelis hakim yang telah ditunjuk oleh Ketua Pengadilan Tinggi Agama untuk diperiksa dan diputus.

b. Proses pemeriksaan dan penyelesaian perkara. Ketentuan dalam proses ini di antaranya: pemeriksaan dilakukan oleh tiga hakim yang bersertifikat ekonomi syariah dan diangkat oleh Ketua Mahkamah Agung. Tata cara pemeriksaan dilakukan tanpa banyak proses, dan putusan diambil berdasarkan berkas perkara. Apabila dianggap perlu Pengadilan Tinggi Agama Semarang dapat melakukan pemeriksaan tambahan yang dituangkan dalam putusan sela yang pelaksanaannya dapat didelegasikan kepada Pengadilan Agama yang memeriksa dan memutus pada tingkat pertama atau dilaksanakan sendiri secara langsung.

c. Proses terakhir adalah pengucapan putusan. Setelah proses pemeriksaan selesai, majelis hakim menjatuhkan putusan atas perkara tersebut. Kemudian salinan putusan 


\section{Mohammad Jamaludin}

dikirimkan ke pengadilan tingkat pertama untuk segera diberitahukan kepada para pihak yang berperkara.

2. Dasar hukum yang digunakan hakim dalam menangani sengketa bisnis adalah ketentuanketentuan dalam UU Nomor 20 Tahun 1947, Peraturan Mahkamah Agung Nomor 14 Tahun 2016, PERMA Nomor 5 Tahun 2016, Rv, HIR, RBg, UU Nomor 7 Tahun 1989, Undang-Undang Nomor 48 Tahun 2009, SEMA Nomor 2 Tahun 2014, Peraturan Mahkamah Agung Nomor 2 Tahun 2009, dan Keputusan Ketua PTA Semarang No. WIIA/2786/HK.00.8/XII/2009.

3. Perspektif cita hukum terhadap penanganan sengketa ekonomi syariah di Pengadilan Tinggi Agama Semarang di antaranya:

a. Ditinjau dari cita hukum keadilan, hakim dalam mewujudkan cita hukum keadilan terkendala secara yuridis dengan ketentuan yang samar dalam tata cara pemeriksaan perkara ekonomi syariah di pengadilan tingkat banding, di antaranya ketidakselarasan ketentuan yang diatur dalam Pasal 15 ayat (1) Undang-Undang Nomor 20 Tahun 1947 dengan ketentuan dalam pasal 2 ayat (4) Undang-Undang Nomor 7 Tahun 1989, Pasal 2 ayat (4) Undang-Undang Nomor 48 Tahun 2009, Surat Edaran Mahkamah Agung Nomor 2 Tahun 2014 dan Peraturan Mahkamah Agung Nomor 2 Tahun 2009. Cita hukum keadilan juga dikaburkan dengan dipergunakannya putusan Mahkamah Agung Nomor $247 \mathrm{~K} / \mathrm{Sip} / 1955$ dalam pertimbangan hukum hakim dalam putusan Pengadilan Tinggi Agama Semarang Nomor 160/Pdt.G/2014/PTA.Smg.

b. Ditinjau dari cita kepastian hukum, kendala dalam proses pemeriksaan disebabkan tidak adanya ketentuan khusus terkait hukum acara perdata dalam tata cara pemeriksaan sengketa ekonomi syariah di pengadilan tingkat banding, kendala lain adalah ketidaktegasan Mahkamah Agung dalam menjelaskan perbedaan konsep antara "Pemeriksaan Ulangan" di dalam Pasal 15 ayat (1) Undang-Undang Nomor 20 tahun 1947 dengan konsep "Pemeriksaan Tambahan" dalam putusan MA Nomor 3136 K/Sip/1983, ditambah lagi terdapat yurisprudensi Mahkamah Agung yang saling bertentangan, yaitu putusan MA Nomor $247 \mathrm{~K} / \mathrm{Sip} / 1953$ dan putusan MA Nomor 112 K/Sip/1955.

c. Ditinjau dari cita hukum kemanfaatan, sebagian telah memenuhi cita hukum kemanfataan karena telah sesuai dengan ketentuan tentang biaya perkara dan jangka waktu penanganan perkara, karena dari 15 putusan Pengadilan Tinggi Agama Semarang semuanya telah sesuai dengan ketentuan yang diatur dalam PERMA Nomor 2 Tahun 2009 dan Keputusan Ketua PTA Semarang Nomor WIIA/2786/HK.00.8/XII/2009, yaitu sebesar Rp. 150.000. Sedangkan untuk jangka waktu penanganan perkara sebagian telah sesuai dengan ketentuan yang diatur dalam SEMA Nomor 2 Tahun 20014, yaitu paling lambat 3 bulan, sedangkan jangka waktu penanganan perkara di PTA Semarang berkisar antara 50 hari sampai 196 hari.

\section{DAFTAR PUSTAKA}




\section{Mohammad Jamaludin}

Abdullah, "Mahkamah Agung Judex Juris ataukah Judex Factie, Pengkajian Asas, Teori, Norma dan Praktik”, Laporan Penelitian, Bogor: Balitbang Pendidikan dan Pelatihan Hukum dan Peradilan Mahkamah Agung RI, 2010.

Arto, A. Mukti, Praktek Perkara Perdata pada Pengadilan Agama, Yogyakarta: Pustaka Pelajar, 1996.

Arto, A. Mukti, Pembaruan Hukum Islam melalui Putusan Hakim, Yogyakarta: Pustaka Pelajar, 2015.

Asikin, Zainal, Hukum Acara Perdata di Indonesia, Jakarta: Kencana, 2015.

Atmadja, I. Dewe Gede, Filsafat Hukum Dimensi Tematis dan Historis, Malang: Setara Press, 2014.

Bakir, Herman, Filsafat Hukum: Desain dan ArsitekturKesejarahan, Bandung: Refika Aditama, 2009.

Bintania, Aris, Hukum Acara Peradilan Agama dalam Kerangka Fiqh al-Qadha, Jakarta: Rajawali Pers, 2012.

Darmodiharjo, Darji dan Shidarta, Pokok-Pokok Filsafat Hukum Apa dan Bagaimana Filsafat Hukum, Jakarta: Gramedia Pustaka Utama, 1995.

Erwin, Muhammad, Filsafat Hukum: Refleksi Kritis terhadap Hukum, Jakarta: Rajawali Pers, 2013.

Hamzah, Moh. Amir, Hukum Acara Perdata Peradilan Tingkat Banding, Malang: Setara Press, 2013.

Harahap, M. Yahya, Kedudukan Kewenangan dan Acara Peradilan Agama: Undang-Undang No. 7 Tahun 1989, Jakarta: Pustaka Kartini, 1997.

Harahap, M. Yahya, Kekuasaan Pengadilan Tinggi dan Proses Pemeriksaan Perkara Perdata dalam Tingkat Banding, Jakarta: Sinar Grafika, 2006.

Harahap, M. Yahya, Hukum Acara Perdata: Gugatan, Persidangan, Penyitaan, Pembuktian dan Putusan Pengadilan, Jakarta: Sinar Grafika, 2014.

Harlen, V., Hukum Acara Perdata dengan Pemahaman Hukum Materiil, Jakarta: Erlangga, 2015.

HS., Salim dan Erlies Septiana Nurbani, Penerapan Teori Hukum pada Penelitian Disertasi dan Tesis:Buku Kedua, Depok: Rajagrafindo Persada, 2015.

Huijbers, Theo, Filsafat Hukum dalam Lintasan Sejarah, Yogyakarta: Kanisius, 1982.

Karen Lebacqz, Teori-Teori Keadilan: Analisis kritis terhadap Pemikiran J.S. Mill, John Rawls, Robert Nozick, Reinhold Neibuhr, Jose Porfirio Miranda,(ed) Ahmad Mustofa, Bandung: Nusa Media, 2011.

Kelsen, Hans, Teori Hukum Murni: Dasar-Dasar Ilmu Hukum Normatif Oleh Hans Kelsen, (ed) Peny. Nurainun Mangunsong,, Bandung: Nusa Media, 2013.

Mahmutarom, Reskontruksi Konsep Keadilan: Studi tentang Perlindungan Korban Tindak Pidana terhadap nyawa menurut Hukum Islam, Konstruksi Masyarakat dan Instrumen Internasional, Semarang: Badan Penerbit Universitas Diponegoro, 2010.

Mappiasse, Syarif, Logika Hukum Pertimbangan Putusan Hakim, Jakarta: Kencana, 2015.

Mardani, Hukum Acara Perdata Peradilan Agama \& Mahkamah Syari'ah, Jakarta: Sinar Grafika, 2009.

Mertokusumo, Sudikno, Hukum Acara Perdata Indonesia, edisi ketiga, Yogyakarta: Liberti, 1988.

Mujahidin, Ahmad, Pembaharuan Hukum Acara Peradilan Agama: dilengkapi format formulir berperkara, Bogor: Ghalia Indonesia, 2012. 


\section{Mohammad Jamaludin}

Nurdin, Boy, Kedudukan dan Fungsi Hakim dalam Penegakan Hukum di Indonesia, Bandung: Alumni, 2012.

Panjaitan, Hulman, Kumpulan Kaidah Hukum Putusan Mahkamah Agung Republik Indoneisa Tahun 1953 s/d 2008 Berdasarkan Penggolongannya, Jakarta: Prenadamedia Group, 2016.

Rifai, Ahmad, Penemuan Hukum oleh Hakim dalam Persfektif Hukum Progresif, Jakarta: Sinar Grafika, 2010.

Rimdan, Kekuasaan Kehakiman Pasca Amandemen Konstitusi, Jakarta: Kencana Prenada Media Group, 2012.

Santoso, M. Agus, Hukum Moral \& Keadilan: Kajian Filsafat Hukum, Jakarta: Kencana, 2012.

Sarwono, Hukum Acara Perdata: Teori dan Praktik, Jakarta: Sinar Grafika, 2011.

Sidharta, Bernard Arief, Refleksi tentang Struktur Ilmu Hukum-Sebuah Penelitian tentang Fundasi Kefilsafatan dan Sifat Keilmuan Ilmu Hukum sebagai Landasan Pengembangan Ilmu Hukum Nasional Indonesia, (Bandung: Mandar Maju, 2000.

Subekti, R., Hukum Acara Perdata, Jakarta: Binacipta, 1981.

Sutantio, Retnowulan dan Iskandar Oeripkartawinata, Hukum Acara Perdata dalam Teori dan Praktek, Bandung: C.V. Mandar Maju, 1997.

Wibowo, Ari, "Mewujudkan Keadilan Melalui Penerapan Hukum Progresif”, dalam Mahrus Ali (ed.), Membumikan Hukum Progresif, Yogyakarta: Aswaja, 2013.

Laporan Tahunan Pengadilan Tinggi Agama Semarang Tahun 2015.

Pokja Laporan Tahunan MARI, Laporan Tahunan 2015 Mahkamah Agung Republik Indonesia, Jakarta: Mahkamah Agung RI, 2016.

Pokja Laporan Tahunan MARI, Laporan Tahunan 2016 Mahkamah Agung Republik Indonesia, Jakarta: Mahkamah Agung RI, 2017.

Pusat Penelitian dan Pengembangan Hukum Mahkamah Agung RI, "Mahkamah Agung sebagai Judex Juris ataukah Judex Factie: Kajian terhadap Asas, Teori dan Praktek”, Laporan Penelitian, Bogor: Pusat Penelitian dan Pengembangan Hukum dan Peradilan Badan Litbang dan Diklat Mahkamah Agung Republik Indonesia, 2013.

Pusat Penelitian dan Pengembangan Mahkamah Agung RI, "Kompetensi Peradilan Agama: Analisis terhadap Putusan Mahkamah Agung RI Mengenai Perkara Ekonomi Syariah Tahun 2006-2012”, Laporan Penelitian, Bogor: Pusat Penelitian dan Pengembangan Mahkamah Agung RI, 2013.

Wijayanta, Tata, Asas Kepastian Hukum, Keadilan dan Kemanfaatan dalam Kaitannya dengan Putusan Kepailitan Pengadilan Niaga dalam Jurnal Dinamika Hukum, Vol 14 No. 2 Mei 2014, Yogyakarta: Fakultas Hukum Universitas Gadjah Mada.

\section{Peraturan Perundang-Undangan}

Het Herziene Indonesich Reglement (HIR).

Peraturan Mahkamah Agung Nomor 2 Tahun 2015 tentang Tata Cara Penyelesaian Gugatan Sederhana.

Peraturan Mahkamah Agung Nomor 5 Tahun 2016 tentang Sertifikasi Hakim Ekonomi Syariah.

Peraturan Mahkamah Agung Nomor 14 Tahun 2016 tentang Tata Cara Penyelesaian Perkara Ekonomi Syariah.

Putusan Mahkamah Agung Republik Indonesia Nomor 951 K/Sip/1973, tanggal 9 Oktober 


\section{Mohammad Jamaludin}

1975.

Putusan Mahkamah Agung Republik Indonesia Nomor 194 K/Sip/1973, tanggal 30 November 1976.

Reglement op de Buitengewesten (RBg).

Reglement op de Burgerlijke Rechtsvordering (Rv)

Undang-Undang Nomor 20 Tahun 1947 tentang Pengadilan Peradilan Ulangan.

Undang-Undang Nomor 7 Tahun 1989 tentang Peradilan Agama.

Undang-Undang Nomor 3 Tahun 2006 tentang Perubahan atas Undang-Undang Nomor 7

Tahun 1989 tentang Peradilan Agama.

Undang-Undang Nomor 50 Tahun 2009 tentang Perubahan Kedua atas Undang-Undang Nomor 7 Tahun 1989 tentang Peradilan Agama.

Undang-Undang Nomor 48 Tahun 2009 tentang Kekuasaan Kehakiman.

Undang-Undang Nomor 5 Tahun 2004 tentang Mahkamah Agung.

\section{Lain-lain}

Amiruddin dan Zaenal Asikin, Pengantar Metodologi Penelitian Hukum, Jakarta: Raja Grafindo Persada, 2008.

Arikunto, Suharsimi, Prosedur Penelitian: Suatu Pendekatan Praktek, Jakarta: Rieneka Cipta, 2002.

Garner, Bryan A., Black's Law Dictionary, Seventh Edition, St. Paul, MINN: West Group, 1999.

Meleong, Lexy J., Metodologi Penelitian Kualitatif, Bandung: RosdaKarya, 2010.

Muhajir, Nong, Metodologi Penelitian Kualitatif, Yogyakarta: Roke Sarasih, 1989.

Soekanto, Soerjono, Pengantar Penelitian Hukum, Jakarta: Raja Grafindo, 2010.

Soemitro, Roni Hanitijo, Metode Penelitian Hukum, Bandung: Sinar Bandung, 1982.

http://putusan.mahkamah.go.id/pengadilan/mahkamah-agung/direktori/perdataagama/ekonomi-syariah, diakses tanggal 13 Desember 2016.

https://putusan.mahkamahagung.go.id/pengadilan/pta-semarang/direktori/perdataagama/ekonomi-syariah, diakses tanggal 13 Desember 2016. 